\title{
Bridging the gap between morphological species and molecular barcodes - Exemplified by loricate choanoflagellates
}

\author{
Frank, Nitsche; Thomsen, Helge Abildhauge; Daniel J, Richter
}

Published in:

European Journal of Protistology

Link to article, DOI:

10.1016/j.ejop.2016.10.006

Publication date:

2017

Document Version

Peer reviewed version

Link back to DTU Orbit

Citation (APA):

Frank, N., Thomsen, H. A., \& Daniel J, R. (2017). Bridging the gap between morphological species and molecular barcodes - Exemplified by loricate choanoflagellates. European Journal of Protistology, 57, $26-37$. https://doi.org/10.1016/j.ejop.2016.10.006

\section{General rights}

Copyright and moral rights for the publications made accessible in the public portal are retained by the authors and/or other copyright owners and it is a condition of accessing publications that users recognise and abide by the legal requirements associated with these rights.

- Users may download and print one copy of any publication from the public portal for the purpose of private study or research.

- You may not further distribute the material or use it for any profit-making activity or commercial gain

- You may freely distribute the URL identifying the publication in the public portal 


\section{Bridging the gap between morphological species and molecular}

barcodes - exemplified by loricate choanoflagellates

Frank Nitsche ${ }^{\mathrm{a} 1}$, Helge Abildhauge Thomsen ${ }^{\mathrm{b}}$ and Daniel J. Richter ${ }^{\mathrm{c}, \mathrm{d}}$

a Zoological Institute, General Ecology, University of Cologne, Zülpicher Str. 47b, 50674 Cologne, Germany

${ }^{b}$ National Institute of Aquatic Resources (DTU Aqua), Technical University of

Denmark, Jægersborg allé 1, DK-2920 Charlottenlund, Denmark

c CNRS, UMR 7144, Station Biologique de Roscoff, Place Georges Teissier, 29680

Roscoff, France

d Sorbonne Universités, Université Pierre et Marie Curie (UPMC) Paris 06, UMR

7144, Station Biologique de Roscoff, Place Georges Teissier, 29680 Roscoff, France

${ }^{1}$ Corresponding author; e-mail FNitsche@uni-koeln.de (F. Nitsche) 


\section{Abstract}

Translating the vast amounts of molecular barcodes from global surveys of microbial eukaryotes into ecological insight depends critically on a well-curated reference database with adequate taxonomic coverage. In this respect, the choanoflagellates resemble other eukaryotic lineages: reasonable coverage at higher taxonomic levels, but missing diversity at the species level. The acanthoecid (loricate) choanoflagellates are well-characterized morphologically, with over 115 species described, but less than $10 \%$ with any sequence data. Because lorica shape is species-specific, the acanthoecids represent an opportunity to link morphological with molecular data within a lineage of eukaryotes. To match morphospecies to sequences, we sampled the Kattegat and the Isefjord in Denmark in September 2014 and February 2015. We identified 45 morphospecies and sequenced ribosomal DNA of nine previously unsequenced species, roughly doubling the number of acanthoecid species with sequence data, including the first data representing five genera: Bicosta, Calliacantha, Cosmoeca, Crinolina and Pleurasiga. Our phylogenetic analysis is mainly congruent with morphology-based systematics. Five of the newly sequenced species match a previously unidentified barcode from Tara Oceans, providing access to the global distribution of species isolated from Danish waters. One species, Calliacantha natans, is the second most globally abundant choanoflagellate present in Tara Oceans. Our project translating new ribosomal DNA sequences to distributions of described species on a global scale supports the approach linking morphology to molecular barcodes for microbial eukaryote ecology.

Keywords: Acanthoecids, Bicostata, Calliacantha, Diaphanoeca, Crinolina, SSU, LSU

\section{Introduction}

The group of acanthoecid (loricate) choanoflagellates is compromised of at present more than 115 described morphospecies (Leadbeater 2015). In general they are ubiquitously found in brackish and marine waters, where they can reach high abundances of up to $3.5 \times 10^{6}$ cells per l-1/Bering Sea (e.g. Sukhanova 2001). The systematics and taxonomy of this group of organisms have undergone substantial changes when analysed with molecular data, in particular the small and large subunit 
(SSU and LSU) of the ribosomal DNA (rDNA) locus. In several cases within choanoflagellates (both loricates and craspedids), it was necessary to modify morphology based taxonomy based on results from molecular phylogeny (Carr et al. 2008). Within the acanthoecid choanoflagellates, two groups were established based on both developmental traits, such as the lorica assembly, and on confirming molecular data. In some cases, species described by morphology and assigned to the same genera do not form a monophyletic group when sequence data produced are analyzed in a phylogenetic tree. An example therefore is Helgoeca nana, which was transferred from the tectiform genus Acanthocorbis to the new, nudiform genus Helgoeca based on phylogenetic and morphologic studies (Leadbeater et al. 2008). In addition, only $10 \%$ of acanthoecid choanoflagellate species have thus far been analysed regarding their molecular identity, in particular with reference to one of the most frequently used and appropriate marker genes, the SSU of the rDNA locus (Pawlowski et al. 2012 ). This lack of molecular data prevents an assignment of next generation sequencing (NGS) data from ongoing molecular barcoding surveys at the species level. In particular, the vast majority of acanthoecid barcodes within the global dataset of the Tara Oceans expedition could not be assigned at the species level. Questions arising when analysing acanthoecid choanoflagellate sequences from public databases include: how many species are there? How variable is the analysed marker gene? How should a species be defined based on this data? This work is aimed to demonstrate the importance of combining morphological and molecular data to understand ecological processes occurring in the complex microbial food web.

\section{Material and Methods}

Sampling was done in Denmark, in September 2014 and February 2015 according to previous records of acanthoecids from this area (Thomsen 1976; Thomsen 1992;

Thomsen et al. 2016).

In addition to surface samples from Isefjord (at Tempelkrogen and Kyndby), a Niskin bottle was used from board of the RV Ophelia to sample underneath the halocline at the field station of DTU Aqua at Helsingoer, The Sound (Table 1). Samples were transported back to the laboratory in a thermically isolated container and immediately processed. In the laboratory, about $500 \mathrm{ml}$ were concentrated on a $2 \mu \mathrm{m}$ Millipore filter using gravity for filtration. Half of this concentrate was transferred in to a petri dish for 
single cell picking. A micromanipulator was used to pick and transfer the morphologically identified single cells to a PCR tube. The other half was further concentrated by centrifugation ( $5 \mathrm{~min}$ at $2000 \mathrm{~g}$ ) and the resulting pellet was fixed using osmium tetroxide vapour for $1 \mathrm{~min}$ on a cover slide. These samples were used for identification and microphotography. Schematic drawings were done based on drawings by Thomsen (1992) using Blender 2.77.

Single cells were amplified using two step PCR. For the first PCR the primer set 42F (5'-CTC AAR GAY TAA GCC ATG CA-3') and 1510R (5'- CCT TCY GCA GGT TCA CCT AC-3') were used, re-amplification was done using the primer set 82F (5'-GAA ACT GCG AAT GGC TC-3') and 1630R (5'- ACC TAC GGA AAC CTT GTT ACG-3') (final primer concentration $0.02 \mu \mathrm{M}$ ). For both reactions the following program was applied: 2 min $98^{\circ} \mathrm{C}$ denaturation followed by 35 cycles of $30 \mathrm{sec}$ at $95^{\circ} \mathrm{C}$ denaturation, $30 \mathrm{sec}$ at $48^{\circ} \mathrm{C}$ and $30 \mathrm{sec}$ at $52^{\circ} \mathrm{C}$ annealing, 2 min at $72^{\circ} \mathrm{C}$ elongation and a final elongation at $72^{\circ} \mathrm{C}$ for $7 \mathrm{~min}$. For LSU rDNA single cells were amplified using the primer set NLF184/21(5'-ACC CGC TGA AYT TAA GCA TAT-3') and NLR3535/22 (5'- MRG GCT KAA TCT CAR YRG ATC G -3') in the first amplification and NLF1105/22 (5'- CCG AAG TTT CCC TCA GGA TAG C -3') and NLR2098/24 (5'- AGC CAA TCC TTW TCC CGA AGT TAC -3') for the reamplification. The PCR program was the same as for SSU, only elongation time was set to $4 \mathrm{~min}$ in the first PCR and $1.5 \mathrm{~min}$ for the reamplification.

PCR products were purified using the Qiagen PCR purification kit according to the manufacturer's instructions. Each purified SSU rDNA PCR product was initially sequenced directly with an ABI 3130xI DNA Sequence Analyzer using the primer C6F (5'- GAC TCA ACA CGG GRA AMC TYA CCA -3'). Positive sequences were sequenced further either by direct sequencing with three additional primers, 82F $\left(5^{\prime}\right.$ GAA ACT GCG AAT GGC TC -3'), V4F (5'- CCA GCA SCY GCG GTA ATT CC -3'), and 1630R (sequence given above), or in cases where the amount of DNA in the PCR product was insufficient for the multiple sequencing reactions that were necessary to produce a complete $18 \mathrm{~S}$ assembly (C. ventriosa, $D$. undulata and $P$. minima) by cloning with the TOPO® TA Cloning $\AA$ Kit into the pCRTM4-TOPO ${ }^{\circledR}$ vector from Life Technologies, according to the manufacturer's instructions, followed by sequencing with V4F and the standard vector-based M13F and M13R primers. LSU rDNA amplicons were treated accordingly only using the primers NLF184/21, NLF1105/22 and NLR2098/24 for sequencing. 
Fragments were assembled manually using Bioedit (Hall 1999). The obtained sequences of SSU and LSU rDNA were used to build a concatenated two gene (SSU and LSU rDNA sequence Table 2), 4470bp (manually corrected) alignment by Kalign2 (gap open penalty 90, gap extention penalty 4, terminal gap penalties 3 and bonus score 0) (Lassmann et al. 2009). This alignment was analysed using Maximum likelihood (ML) and Bayesian inference (BI) methods. ML analysis was computed by RAxML (Stamatakis et al. 2008) using the RAxML GAMMA+P-Invar model of rate heterogeneity, as suggested by MrAic (Ronquist and Huelsenbeck 2003) and run using a GTR+I model and a four-category gamma distribution to model among-site rate variation, 1000 bootstrap replicates (rapid bootstrapping). The Bayesian inference search, computed by MrBayes 3.2.6 (Ronquist, Huelsenbeck, 2003) consisted of two parallel chain sets run at default temperatures with a sampling frequency of 10 , run until the average standard deviation of split frequencies dropped below 0.01 . The analysis consisted of $3,500,000$ generations, with a burnin of 87,500 , before calculating posterior probabilities. The choanoflagellates were rooted with a clade consisting of two ichthyosporean taxa (Nitsche 2014).

In order to identify Tara Oceans OTUs corresponding to the 9 species we sequenced, we extracted the V9 region of the $18 \mathrm{~S}$ sequence for each species. We then searched for matching OTUs in the Tara Oceans data using a similar strategy to the one implemented in order to construct the OTUs (Mahé et al., 2014, de Vargas et al., 2015). We searched within the database of Tara Oceans V9 barcodes for either perfect matches or for matches with exactly one difference between our nine new sequences and a Tara Oceans V9 barcode using the alignment software Sumatra version 1.0.10 (https://git.metabarcoding.org/obitools/sumatra/wikis/home). We visualized these matches using network diagrams (Figure 4) with Cytoscape version 3.2.1 (Shannon et al., 2003). The idea of this approach is that many rare barcodes may be present in a sample simply due to PCR error, because of the massive amount of barcodes that were sequenced. If this is true, then when we build a network of barcodes, drawing connections between barcodes if there is exactly one DNA sequence difference between them, then the "true" barcode will be highly abundant, and will be surrounded by a "swarm" of much less abundant sequences that represent sporadic PCR errors (which may also be errors occurring on intermediate PCR products that already contained one or more errors). To create maps for each newly affiliated Tara Oceans OTU, we used the GPS coordinates of 
each sampled station provided by the Tara Oceans Consortium (Tara Oceans Consortium, 2014, Pesant et al., 2015) and relative abundances for each OTU for the 0.8-5 $\mu \mathrm{m}$ and 5-20 $\mu \mathrm{m}$ size fractions (de Vargas et al., 2015). Although several of the species we describe may construct loricae measuring larger than $5 \mu \mathrm{m}$ (or even larger than $20 \mu \mathrm{m}$ ), we found the majority of the abundance for each species within the 0.8-5 $\mu \mathrm{m}$ size fraction, and nearly all of the abundance within the 0.8-5 $\mu \mathrm{m}$ and 5$20 \mu \mathrm{m}$ size fractions. We hypothesize that this occurs due to the filtration process, during which cells are likely pulled out of their loricae. There were only four cases in which a species was observed in either the 20-180 $\mu \mathrm{m}$ or 180-2000 $\mu \mathrm{m}$ size fractions, but not in the two smaller size fractions; in three of these cases, only 1 total barcode was observed outside the two smaller size fractions, and in one case, 4 barcodes were observed, amounts we considered to be below the threshold required to present the data on a map. We created the maps using $\mathrm{R}$ version 3.3.0 ( $\mathrm{R}$ Core Team, 2016) using the following packages: data.table version 1.9.6 (Dowle et al., 2015), ggplot2 version 2.1.0 (Wickham, 2009) and maps version 3.1.0 (Brownrigg, 2016).

\section{Results}

Based on sampling from Danish waters, we were able to isolate, sequence and neotypify nine previously unsequenced morphospecies and five yet unsequenced genera of acanthoecid choanoflagellates: Bicosta minor, Calliacantha longicaudata, C. natans, Cosmoeca ventricosa, Crinolina isefiordensis, Diaphanoeca sphaerica, $D$. undulata, Pleurasiga minima and $P$. reynoldsii. All species could be maintained for a few days only in mixed cultures, containing environmental bacteria and other protists. An isolation and establishment of monocultures was not successful. For all species, schematic 3D drawings for clear lorica architecture (Fig 1A-I) and LM micrographs $(2 A-M)$ are provided alongside phylogenetic analysis based on SSU and LSU rDNA (Fig 3).

Bicosta minor (Reynolds) Leadbeater 1978; Fig. $1 \mathrm{~A}$

Additional references: Bérard-Therriault et al. 1999; Manton et al. 1980; Marchant 2005; Thomsen 1982; Tong 1997

Global distribution in Tara Oceans Data: no identical or nearly identical match in the Tara Oceans V9 database (Table 3). 
Remarks: Marine tectiform acanthoecid, single cell isolated from a Kyndby sample collected 23 February 2015 (Table 1). Identification based on the original description, neotypified to relate a morphotype to genotype.

Emended diagnosis: Tectiform, cells solitary, lorica 11-45 $\mu \mathrm{m}$ in length, composed of seven costal strips arranged as two longitudinal costae, and by two costal strips each with tapered tips anteriorly and a posterior spine. (Fig $1 \mathrm{~A}$ and $2 \mathrm{~A}-\mathrm{C}$ ). The closest relative of the SSU rDNA sequence in NCBI GenBank, based on nucleotide BLAST results, is an uncultured choanoflagellate from the Scotia Sea (KC488357) at 98\% identity.

Neotype sequence data: The SSU rDNA sequence of $B$. minor has been deposited in the GenBank database with the accession number KU587839.

Calliacantha longicaudata (Leadbeater) Leadbeater 1978; Fig. 1C

Additional references: Bérard-Therriault et al. 1999; Leadbeater 2015; Marchant 2005; McKenzie et al. 1997; Thomsen 1982; Thomsen 1992; Thomsen et al. 1997. Global distribution in Tara Oceans Data: no identical or nearly identical match in the Tara Oceans V9 database (Table 3).

Remarks: Marine tectiform acanthoecid, found at Kyndby (Table 1). Identification based on the original description, neotypified to relate a morphotype to genotype. Emended diagnosis: Tectiform, cells solitary, lorica without stalk 11-18 $\mu \mathrm{m}$ in length, composed of five longitudinal costae each composed of two costal strips. Two transverse costae are linked to the anterior longitudinal strips, leaving the ultimate tips of the anterior costae as projecting spines. The pedicel is composed of a variable number of costal strips (Figs. $1 \mathrm{C}$ and $2 \mathrm{E}$ ).

The closest relative of the SSU rDNA sequence in NCBI GenBank, based on nucleotide BLAST results, is an uncultured choanoflagellate from the Scotia Sea (KC488358) at $99.6 \%$ identity.

Neotype sequence data: The SSU and LSU rDNA sequences of $C$. longicaudata have been deposited in the GenBank database with the accession numbers KU587840 and KU587841, respectively.

Calliacantha natans (Grøntved) Leadbeater 1978; Fig. 1B 
Additional references: Bérard-Therriault et al. 1999; Buck and Garrison 1983; Leadbeater 1972; Leadbeater 2015; Manton and Leadbeater 1978; Marchant 2005; Thomsen 1982; Thomsen et al. 1990; Throndsen 1993; Tong 1997 Global distribution in Tara Oceans Data: Fig. 5A (Table 3). Remarks: Marine tectiform acanthoecid, found at Kyndby and Tempelkrogen (Table 1). Identification based on the original description, neotypified to relate a morphotype to genotype.

Emended diagnosis: Tectiform, cells solitary, lorica 20-60 $\mu \mathrm{m}$ in length, formed by six longitudinal costae and two transverse costae, one of which forms the anterior ring. Posterior end of lorica chamber tapers and joins with a single spine, while three spines emerge from the anterior transverse ring (Figs. 1B and $2 \mathrm{~F}$ ).

The closest relative of the SSU rDNA sequence in NCBI GenBank, based on nucleotide BLAST results, is an uncultured choanoflagellate from the Scotia Sea (KC488358) at 98\% identity.

Neotype sequence data: The SSU and LSU rDNA sequences of $C$. natans have been deposited in the GenBank database with the accession numbers KU587842 and KU587843, respectively.

Cosmoeca ventricosa Thomsen 1984 in Thomsen and Boonruang 1984; Fig. 1D Additional references: Bérard-Therriault et al. 1999; Booth 1990; Leadbeater 2015; Marchant 2005; Thomsen et al. 1990; Tong 1997

Global distribution in Tara Oceans Data: no identical or nearly identical match in the Tara Oceans V9 database (Table 3).

Remarks: Marine tectiform acanthoecid, found at Helsingør, 20m (Table 1). Identification based on the original description, neotypified to relate a morphotype to genotype.

Emended diagnosis: Tectiform, cells solitary, lorica 23-32 $\mu \mathrm{m}$ in length, barrel-shaped, composed of 3 transverse costae and 8-12 longitudinal costae. Two almost equally sized anterior transverse costae located at the anterior end of the lorica chamber and at the level of the joints between the second and the third longitudinal costal strip. Same number of strips in anterior transverse costae as there are longitudinal costae. Third transverse costa narrower, formed by 3-4 costal strips, positioned between the third and fourth longitudinal strip (Figs. 1D and 2G). 
The closest relative of the SSU rDNA sequence in NCBI GenBank, based on nucleotide BLAST results, is an uncultured choanoflagellate from the Baltic Sea (FN690465) at 99\% identity.

Neotype sequence data: The SSU rDNA sequence of $C$. ventricosa has been deposited in the GenBank database with the accession number KU587844.

\section{Crinolina isefiordensis Thomsen 1976; Fig. 1E}

Additional references: Bérard-Therriault et al. 1999; Leadbeater 2015; Thomsen 1982; Throndsen 1993; Tong 1997.

Global distribution in Tara Oceans Data: Fig. 5B (Table 3).

Remarks: Marine tectiform acanthoecid, found at Tempelkrogen (Table 1). Identification based on the original description, neotypified to relate a morphotype to genotype.

Emended diagnosis: Tectiform, cells solitary, lorica 25-30 $\mu \mathrm{m}$ in length, skirt-shaped, open anteriorly and posteriorly. 14-15 longitudinal costae composed of 6-7 costal strips. Anteriorly longitudinal spines from two costal strips protrude above anterior transverse ring, posteriorly longitudinal costae slightly project beyond the transverse ring (Figs. 1E and $2 \mathrm{H}$ ). The closest relative of the SSU rDNA sequence in NCBI GenBank, based on nucleotide BLAST results, is an uncultured choanoflagellate from the Arctic Ocean, north of Barrow, Alaska (KJ762435) at 96\% identity. Neotype sequence data: The SSU rDNA sequence of $C$. isefiordensis has been deposited in the GenBank database with the accession number KU587845.

\section{Diaphanoeca sphaerica Thomsen 1982; Fig. 1G}

Additional references: Marchant 2005; Marchant and Perrin 1986.

Global distribution in Tara Oceans Data: no identical or nearly identical match in the Tara Oceans V9 database (Table 3).

Remarks: Marine tectiform acanthoecid, found at Tempelkrogen and Kyndby (Table 1). Identification based on the original description, neotypified to relate a morphotype to genotype.

Emended diagnosis: Tectiform, cells solitary, lorica 22-30 $\mu \mathrm{m}$ in length and 16-17 $\mu \mathrm{m}$ in diameter, bell-shaped, formed by 13-15 longitudinal costae composed of 9-10 strips each, and three transverse costae. In the two anterior transverse costae the number of strips equals the number of longitudinal costae, whereas the posterior 
transverse costa contains fewer strips. Posterior lorica end with irregularly arranged costal strips. Large colony formations frequently found (Figs. 1G and 2I, J). The closest relative of the SSU rDNA sequence in NCBI GenBank, based on nucleotide BLAST results, is Diaphanoeca grandis (AF084234) at 99\% identity. Neotype sequence data: The SSU and LSU rDNA sequences of $D$. sphaerica have been deposited in the GenBank database with the accession numbers KU587846 and KU587847, respectively.

Diaphanoeca undulata Thomsen 1982; Fig. 1F

Additional references: Thomsen 1992

Global distribution in Tara Oceans Data: Fig. 5C (Table 3).

Remarks: Marine tectiform acanthoecid, found at Helsingør, 20m (Table 1). Identification based on the original description, neotypified to relate a morphotype to genotype.

Emended diagnosis: Tectiform, cells solitary, lorica up to $30 \mu \mathrm{m}$ in length without posterior pedicel, with posterior pedicel up to $50 \mu \mathrm{m}$ long. 11-12 longitudinal costae, composed of 5 costal strips and three transverse costae form the lorica chamber.

Anterior transverse costa crosses longitudinal costae at the junction between the first and second strip, leaving the first strips as free projecting spines. The middle transverse costa, which has an undulating appearance, crosses anterior to the joints between the second and the third longitudinal costal strip (Figs. $1 \mathrm{~F}$ and $2 \mathrm{~K}$ ). The closest relative of the SSU rDNA sequence in NCBI GenBank, based on nucleotide BLAST results, is an uncultured choanoflagellate from the Arctic Ocean, north of Barrow, Alaska (KJ762435) at 98\% identity.

Neotype sequence data: The SSU rDNA sequence of $D$. undulata has been deposited in the GenBank database with the accession number KU587848.

Pleurasiga minima Throndsen 1970; Fig. 1H

Additional references: Bérard-Therriault et al. 1999; Hallegraeff 1983 ; Manton et al. 1976; Marchant 2005; Thomsen 1976; Thomsen 1982; Thomsen and Buck 1991;

Tong 1997

Global distribution in Tara Oceans Data: Fig. 5D (Table 3). 
Remarks: Marine tectiform acanthoecid, found in Tempelkrogen (Table 1). Identification based on the original description, neotypified to relate a morphotype to genotype.

Emended diagnosis: Tectiform, cells solitary, lorica 10-14 $\mu \mathrm{m}$ in height and 10-12 $\mu \mathrm{m}$ in width, amphora-shaped, two transverse, nearly equally wide costae, 7 longitudinal costae composed of 3 costal strips. Costal strip connections are, anteriorly, T-joints (Figs. $1 \mathrm{H}$ and 2L).

The closest relative of the SSU rDNA sequence in NCBI GenBank, based on nucleotide BLAST results, is an uncultured choanoflagellate from the Arctic Ocean, north of Barrow, Alaska (KJ763316) at $97 \%$ identity.

Neotype sequence data: The SSU and LSU rDNA sequences of $P$. minima have been deposited in the GenBank database with the accession numbers KU587849 and KU587850, respectively.

Pleurasiga reynoldsii Throndsen 1970; Fig.1I

Additional references: Marchant 2005; Thomsen 1982; Thomsen and Buck 1991;

Throndsen 1993; Throndsen 1970

Global distribution in Tara Oceans Data: Fig. 5E (Table 3).

Remarks: Marine tectiform acanthoecid, found in Tempelkrogen (Table 1).

Identification based on the original description, neotypified to relate a morphotype to genotype.

Emended diagnosis: Tectiform, cells solitary, lorica up to $23 \mu \mathrm{m}$ in height and up to $22 \mu \mathrm{m}$ in width, amphora-shaped, posterior transverse costae about $1 / 3$ wider than anterior costae composed from 7 costal strips, 7 longitudinal costae between anterior and posterior costae composed by two costal strips, merging branch like into 4 terminal costae (Figs. 11 and $2 \mathrm{M}$ ).

The closest relative of the SSU rDNA sequence in NCBI GenBank, based on nucleotide BLAST results, is an uncultured choanoflagellate from the Gulf Stream, North Atlantic (KJ759457) at 95\% identity.

Neotype sequence data: The SSU and LSU rDNA sequences of $P$. reynoldsii have been deposited in the GenBank database with the accession numbers KU587851 and KU587852, respectively. 
Species from the genus Diaphanoeca form a well-supported cluster in the concatenated SSU and LSU analysis (Fig. 3). D. sphaerica and D. undulata branch together with $D$. grandis and $D$. spiralifurca. Crinolina isefiordensis, a morphologically similar species, clusters within the same group, indicating a possible paraphyly or polyphyly (neither state is robustly supported) of Diaphanoeca.

The two species from the genus Calliacantha, $C$. longicaudata and $C$. natans, form a monophyletic group with high bootstrap support. The genus Pleurasiga, represented by $P$. minima and $P$. reynoldsii, also forms a monophyletic group with strong support. Finally, Cosmoeca ventricosa and Bicosta minor cluster together with Acanthocorbis unguiculata. Although this branching pattern has high bootstrap support, the different morphology of these species indicates that a subsequent incorporation of additional sequences representing each genus may cause the pattern to change.

We detected 5 operational taxonomic units (OTUs) within Tara Oceans V9 hypervariable region SSU data perfectly matching one of the 9 newly sequenced species (de Vargas et al., 2015). Each OTU was previously classified as a choanoflagellate, but lacked a species identification. These OTUs correspond to $C$. natans, $C$. isefiordensis, $D$. undulata, $P$. minima and $P$. reynoldsii (Table 3 , Fig. 4). We did not detect perfect matches for B. minor, C. longicaudata, $C$. ventricosa or $D$. undulata, although in each case our new sequence was an equal or better match to the Tara OTU sequence than any existing sequences in GenBank. One of the newly identified species, $C$. natans, is the second most globally abundant choanoflagellate present within Tara Oceans V9 data. Its $18 \mathrm{~S}$ V9 sequence is distantly related to any sequence currently in GenBank (the closest match is to Didymoeca costata at $88 \%$ identity). A network-based analysis comparing our new sequences to Tara V9 barcodes showed that, in all cases except for one, these sequences matched the most abundant barcode within the OTU identified. In the case of $P$. reynoldsii, it is possible that our new sequence might contain a single error, since there are no other sequences within 1 difference of any sequences within this OTU in the Tara V9 database (Fig. 4).

The five newly sequenced species present in Tara Oceans data display a range of distributions in a global context. Calliacantha natans (Fig. 5A), the second most abundant choanoflagellate in Tara Oceans data (Table 3), and Diaphanoeca undulata, the $16^{\text {th }}$ most abundant (Fig. 5C) are found in nearly every station and ocean basin studied, with the exception of the northern Indian Ocean (where the 
craspedid Monosiga brevicollis appears to be the dominant choanoflagellate; de Vargas et al., 2015). Both of these species are also found at their highest relative abundances in the cold water stations of the Antarctic, the South Atlantic, and the cold water coastal upwelling off the Horn of Africa (Supplementary Figs. S1 and S2). The two newly sequenced Pleurasiga species, $P$. minima and $P$. reynoldsii, are detected in the South Atlantic and the Antarctic, at the boundary between the Indian Gyre and the South Atlantic Gyre off the coast of South Africa, at an upwelling station off the west coast of South America, and in the Mediterranean (Figs. 5D, E). As is the case for $C$. natans and D. undulata, the two Pleurasiga species are also observed at their highest relative abundances in the cold water stations of the southern hemisphere (Supplementary Figs. S4, S5). Crinolina isefiordensis, by far the least abundant of the newly sequenced species, is found in only two stations world-wide (Fig. 5B, Supplementary Fig. S3).

\section{Discussion}

Within a short time and with comparably little effort we were able to roughly double the number of acanthoecid choanoflagellates with sequence data available in public databases. The genus Diaphanoeca is a good example of consensus between morphology and phylogenetic analysis, as all species form a well-supported cluster (Fig. 3). The presence of Crinolina within this cluster may be well justified by the similar morphology of the two genera. The genus Crinolina, in particular the type species $C$. isefiordensis, was characterized by the lorica being open posteriorly. Although it is closely related to Diaphanoeca (Thomsen 1976) in its morphology, it is well distinguishable. As, at present, there is no sequence from the type species $C$. aperta available, we refrain from transferring $C$. isefiordensis to the genus Diaphanoeca, as it might instead turn out to be a sister genus when additional sequence data become available. In addition the nested position of $C$. isefiordiensis lacks strong phylogenetic support.

Pleurasiga and Calliacantha also form highly supported clusters (Fig. 3). Thus, the phylogeny created with concatenated sequences of SSU and LSU rDNA confirmed the coherence of both genera. However, within our data set the monophyletic origin of the Stephanoecida cannot be considered robustly resolved on phylogenetic grounds. Adding housekeeping genes like HSP90 or $\alpha$-tubulin might help to resolve this issue (Leadbeater et al. 2008; Nitsche et al. 2011), but these genes could not be 
analysed in this study. Nevertheless, the nudiform species, Acanthoecida, are recovered as a monophyletic group. A future enhancement to our single-cell sequencing approach could include whole genome amplification of single cells to obtain sufficient DNA for the analysis of other marker genes (Krabberød et al. 2011). Despite the fact that our sampling was conducted exclusively in Danish waters, we detect an essentially global distribution for the species we sequenced with matching OTUs in the Tara Oceans expedition (which did not directly sample Danish waters). This result echoes previous observations of choanoflagellates as ubiquitous in aquatic environments, while providing evidence that single species are also found across all ocean basins. In addition, this highlights the fact that a local sampling approach can be translated via sequence barcodes to information on species distributions at a global level. Using these sequences, it should now be possible to link previous descriptions of species distribution using morphology directly to distributions from Tara and other surveys based on ribosomal sequence data. Within our sequences, we succeeded in providing an identification for the second most globally abundant choanoflagellate in Tara Oceans data, Calliacantha natans. $C$. natans and the other species we identify in Tara Oceans data display their highest relative abundances in cold water Tara sampling stations. The highest relative abundance for any newly sequenced species is that of $C$. natans in the $0.8-5 \mu \mathrm{m}$ size fraction at the surface located off the coast of Argentine Patagonia, where it represents nearly $1 \%$ of the total abundance of all 2,828 OTUs detected, and is the seventh most abundant OTU. Thus, within our sample of only five newly sequenced loricate choanoflagellates, we are able to detect a global distribution for each species and to attest to the importance of individual species within individual microbial food webs.

In addition, our approach should also be applicable to other groups of microbial eukaryotes whose morphology is species-specific but which lack extensive associated molecular barcoding data. Depositing ribosomal sequence data, such as those we collected in this study, into curated databases like the Protist Ribosomal Reference database (Guillou et al. 2013) is a valuable and necessary addition to help resolve the flood of data acquired by High Throughput Sequencing technologies. Concluding we can answer the questions posed in the introduction - the number of described acanthoecid morphospecies, 115, and the number of acanthoecid OTUs from Tara Ocean data, 129 correlate well. This result indicates that about $10 \%$ of 
loricates have not been described yet. Therefore we find that the SSU rDNA is a suitable marker gene for species determination as shown in previous studies (Nitsche and Arndt 2015; Pawlowski et al. 2012 ). On the other hand we find that for species characterisation, morphology and sequence data still need to be supplemented with autecological data as salinity and temperature tolerance are required to interpret for example global distribution patterns.

\section{Acknowledgements}

We thank colleagues at the University of Copenhagen Marine Biological Section (Elsinore), in particular Per Juel Hansen and Lasse Riemann, for providing us with excellent laboratory facilities during our Sept. 2014 field campaign. We also thank colleagues at the University of Copenhagen Marine Biological Section (Copenhagen), in particular Gert Hansen, for providing us with excellent laboratory facilities during our Feb./March 2015 field campaign. The Natural History Museum of Denmark, University of Copenhagen, kindly gave us access to their DNA laboratories. Special thanks goes to Nina Lundholm and Charlotte Hansen. We acknowledge Marie-José Garet-Delmas for assistance with Sanger sequencing. We also thank Stéphane Audic and Nicolas Henry for assistance in searching databases and preparing figures based on Tara Oceans data. We thank two anonymous reviewers for their comments that improved this manuscript. DJR was supported by a postdoctoral fellowship from the Conseil Régional de Bretagne, and the French Government "Investissements d'Avenir" program OCEANOMICS (ANR-11-BTBR-0008). 


\section{References}

Bérard-Therriault, L., Poulin, M., Bossé, L. 1999. Guide d'identification du phytoplancton marin de l'estuaire et du Golfe du Saint-Laurent, incuant également certains protozoaires. Les Presses Scientifique du CNRC, Ottawa.

Booth, B.C. 1990. Choanoflagellates from the Sub-Arctic North Pacific-Ocean, with Descriptions of 2 New Species. Can. J. Zool. 68, 2393 -2402.

Brownrigg, R., Becker, R.A., Wilks, A.R., Minka, T.P., Deckmyn, A. 2016. maps: Draw Geographical Maps. R package version 3.1.0. https://CRAN.Rproject.org/package $=$ maps

Buck, K.R., Garrison, D.L. 1983. Protists from the ice-edge region of the Weddell Sea. Deep-Sea Res. 30, 1261 -1277.

Carr, M., Leadbeater, B.S.C., Hassan, R., Nelson, M., Baldauf, S.L. 2008. Molecular phylogeny of choanoflagellates, the sister group to Metazoa. P. Natl. Acad. Scie. USA 105, $16641-16646$.

de Vargas, C., Audic, S., Henry, N., Decelle, J., Mahé, F., Logares, R., Lara, E., Berney, C., Le Bescot, N., Probert, I., Carmichael, M., Poulain, J., Romac, S., Colin, S., Aury, J.M., Bittner, L., Chaffron, S., Dunthorn, M., Engelen, S., Flegontova, O., Guidi, L., Horák, A., Jaillon, O., Lima-Mendez, G., Lukeš, J., Malviya, S., Morard, R., Mulot, M., Scalco, E., Siano, R., Vincent, F., Zingone, A., Dimier, C., Picheral, M., Searson, S., Kandels-Lewis, S.; Tara Oceans Coordinators, Acinas, S.G., Bork, P., Bowler, C., Gorsky, G., Grimsley, N., Hingamp, P., ludicone, D., Not, F., Ogata, H., Pesant, S., Raes, J., Sieracki, M.E., Speich, S., Stemmann, L., Sunagawa, S., Weissenbach, J., Wincker, P., Karsenti, E. 2015. Eukaryotic plankton diversity in the sunlit ocean. Science 22, 348(6237):1261605. doi: 10.1126/science.1261605.

Dowle, M., Srinivasan, A., Short, T., Lianoglou, S., Saporta, R., Antonyan, E. 2015. data.table: Extension of Data.frame. R package version 1.9.6. https://CRAN.Rproject.org/package=data.table.

Guillou, L., Bachar, D., Audic, S., Bass, D., Berney, C., Bittner, L., Boutte, C., Burgaud, G., de Vargas, C., Decelle, J., del Campo, J., Dolan, J.R., Dunthorn, M., Edvardsen, B., Holzmann, M., Kooistra, W.H., Lara, E., Le Bescot, N., Logares, R., Mahe, F., Massana, R., Montresor, M., Morard, R., Not, F., Pawlowski, J., Probert, I., Sauvadet, A.L., Siano, R., Stoeck, T., Vaulot, D., Zimmermann, P., Christen, R. 2013. The Protist Ribosomal Reference database (PR2): a catalog of unicellular eukaryote Small Sub-Unit rRNA sequences with curated taxonomy. Nucleic Acids Res. 41, $597-604$.

Hall, T.A. 1999. BioEdit: a user-friendly biological sequence alignment editor and analysis program for Windows 95/98/NT. Nucleid Acids Symp. 41, 95 -98.

Hallegraeff, G.M. 1983. Scale-bearing and loricate nanoplankton from the East Australian current. Bot. Mar. 26, $493-516$. 
Krabberød, A.K., Bråte, J., Dolven, J.K., Ose, R.F., Klaveness, D., Kristensen, T., Bjørklund, K.R., Shalchian-Tabrizi, K. 2011 Radiolaria divided into Polycystina and Spasmaria in combined $18 \mathrm{~S}$ and $28 \mathrm{~S}$ rDNA phylogeny. PLoS ONE 6, e23526. doi: 10.1371/journal.pone.0023526

Lassmann, T., Frings, O., Sonnhammer, E.L. 2009 Kalign2: high-performance multiple alignment of protein and nucleotide sequences allowing external features. Nuc. Acids Res. 37, 858 -865.

Leadbeater, B.S.C. 1972. Ultrastructural observations on some marine choanoflagellates from the coast of Denmark. Brit. Phycol. J. 7, 195 -211.

Leadbeater, B.S.C. 1978. Renaming of Salpingoeca Sensu Grontved. J. Mar. Bio. Assoc. UK 58, $511-515$.

Leadbeater, B.S.C. 2015. The Choanoflagellates - Evolution, Cell biology, Ecology. Camebridge University Press, Camebridge.

Leadbeater, B.S.C, Hassan, R., Nelson, M., Carr, M., Baldauf, S.L. 2008. A new genus, Helgoeca gen. nov., for a nudiform choanoflagellate. Eur. J. Protistol. 44, 227 -237 .

Mahé, F., Rognes, T., Quince, C., de Vargas, C., Dunthorn, M. 2014. Swarm: robust and fast clustering method for amplicon-based studies. PeerJ.,2:e593. doi:

10.7717/peerj.593.

Manton, I., Leadbeater, B.S.C. 1978 Some critical qualitative details of lorica construction in type species of Calliacantha Leadbeater (Choanoflagellata). P. Roy. Soc. Lond. B. Bio. 203, $49-57$.

Manton, I., Sutherland, J., Leadbeater, B.S.C. 1976. Further observations on finestructure of marine collared flagellates (Choanoflagellata) from Arctic Canada and West Greenland - Species of Parvicorbicula and Pleurasiga. Can. J. Zool. 54, 1932 1955.

Manton, I., Sutherland, J., Oates, K. 1980. A reinvestigation of collared flagellates in the Genus Bicosta Leadbeater with special reference to correlations with climate. Phil. T. Roy. Soc. B 290, $431-447$.

Marchant, H.J. 2005. Choanoflagellates. In: Scott FJ, Marchant HJ (Eds.), Antarctic Marine Protists. Australian Biological Resource Studies, Canberra and Australian Antarctic Division, Canberra and Hobbart, pp. 326-346.

Marchant, H.J., Perrin, R.A. 1986. Planktonic choanoflagellates from 2 Antarctic lakes including the description of Spiraloecion didymocostatum gen. et sp. nov. Polar Biol. 5, 207 -210.

McKenzie, C.H., Deibel, D., Thompson, R.J., MacDonald, B.A., Penney, R.W. 1997. Distribution and abundance of choanoflagellates (Acanthoecidae) in the coastal cold ocean of Newfoundland, Canada. Marine Biol. 129, 407 -416. 
Nitsche, F. 2014. Stephanoeca arndti spec. nov - First cultivation success including molecular and autecological data from a freshwater acanthoecid choanoflagellate from Samoa. Eur. J. Protistol. 50, 412 -421.

Nitsche, F., Arndt, H. 2015. Comparison of similar Arctic and Antarctic morphotypes of heterotrophic protists regarding their genotypes and ecotypes. Protist 166, $42-57$.

Nitsche, F., Carr, M., Arndt, H., Leadbeater, B.S.C. 2011. Higher Level Taxonomy and Molecular Phylogenetics of the Choanoflagellatea. J. Eukaryot. Microbiol. 58, $452-462$.

Nylander, J.A.A. 2003. MrAIC.pl. Programm distributed by the author. Evolutionary Biology Centre, Uppsala University, Uppsala.

Pawlowski, J., Audic, S., Adl, S., Bass, D., Belbahri, L., Berney, C., Bowser, S.S., Cepicka, I., Decelle, J., Dunthorn, M., Fiore-Donno, A.M., Gile, G.H., Holzmann, M., Jahn, R., Jirku, M., Keeling,, P.J., Kostka, M., Kudryavtsev, A., Lara, E., Lukes, J., Mann, D.G., Mitchell, E.A., Nitsche, F., Romeralo, M., Saunders, G.W., Simpson, A.G., Smirnov, A.V., Spouge, J.L., Stern, R.F., Stoeck, T., Zimmermann, J., Schindel, D., de Vargas, C. 2012. CBOL Protist working group: Barcoding eukaryotic richness beyond the animal, plant, and fungal kingdoms. PLOS Biol. 10, doi:10.1371/journal.pbio.1001419.

Pesant, S., Not, F., Picheral, M., Kandels-Lewis, S., Le Bescot, N., Gorsky, G., ludicone, D., Karsenti, E., Speich, S., Troublé, R., Dimier, C., Searson, S. 2015. Tara Oceans Consortium Coordinators. Open science resources for the discovery and analysis of Tara Oceans data. Scientific Data. 2, 150023. doi:

10.1038/sdata.2015.23.

R Core Team 2016. R: A language and environment for statistical computing. $R$ Foundation for Statistical Computing, Vienna, Austria. URL https://www.Rproject.org/.

Ronquist, F., Huelsenbeck, J.P. 2003. MrBayes 3: Bayesian phylogenetic inference under mixed models. Bioinformatics 19, 1572 -1574.

Shannon, P., Markiel, A., Ozier, O., Baliga, N.S., Wang, J.T., Ramage, D., Amin, N., Schwikowski, B., Ideker, T. 2003 Cytoscape: a software environment for integrated models of biomolecular interaction networks. Gen.Research 13, 2498-

504.Stamatakis, A., Hoover, P., Rougemont, J. 2008. A Rapid Bootstrap Algorithm for the RAxML Web Servers. Syst. Biol. 57, $758-771$.

Sukhanova, I.N. 2001. Choanoflagellida on the southeastern Bering Sea shelf. Oceanology 41, $227-231$.

Tara Oceans Consortium, Coordinators; Tara Oceans Expedition, Participants (2014): Registry of selected samples from the Tara Oceans Expedition (2009-2013). doi:10.1594/PANGAEA.840721.

Thomsen, H.A. 1976. Studies on marine choanoflagellates II. Fine- structural observations on some silicified choanoflagellates from the Isefjord (Denmark), including the description of two new species. Norw. J. Bot. 23, $33-51$. 
Thomsen, H.A. 1982. Planktonic Choanoflagellates from Disko Bugt, West Greenland, with a survey of the marine nanoplankton of the area. Commission for Scientific Research in Greenland.

Thomsen, H.A. 1992. Loricabærende choanoflagellater (Kraveflagellater). Plankton in Plankton i de indre danske farvande 11, 157 -194.

Thomsen, H.A., Buck, K.R., Coale, S.L., Garrison, D.I., Gowing, M.M. 1990. Loricate Choanoflagellates (Acanthoecidae, Choanoflagellida) from the Weddell Sea, Antarctica. Zool. Scr. 19, 367 -387.

Thomsen, H.A., Buck, K.R. 1991. Choanoflagellate diversity with particular emphasis on the Acanthoecidae. In: Patterson DJ, Larsen J (Eds.), The Biology of Free-Living Heterotrophic Flagellates. Clarendon Press, Oxford, pp. 259-184.

Thomsen, H.A., Garrison, D.L., Kosman, C. 1997. Choanoflagellates (Acanthoecidae, Choanoflagellida) from the Weddell Sea, Antarctica, taxonomy and community structure with particular emphasis on the ice biota; With preliminary remarks on choanoflagellates from Arctic Sea Ice (Northeast Water Polynya, Greenland). Arch. Protistenk. 148, 77 -114.

Throndsen, J. 1993. The planktonic marine flagellates. In: Tomas CR (Ed.), Marine Phytoplankton: a guide to naked flagellates and coccolithophorids. Academic Press, San Diego, pp. 7-145.

Throndsen, J. 1970. Marine planktonic Acanthoecaceans (Craspedophyceae) from Arctic waters. Nytt, Mag. Bot. 17, $103-111$.

Tong, S.M. 1997. Choanoflagellates in Southampton water, including the description of three new species. J. Mar. Biol. Assoc. UK 77, 929 -958.

Wickham, H 2009. ggplot2: Elegant Graphics for Data Analysis. Springer-Verlag New York. 
Figure 1. Schematic drawings of the species from this study. (A) Bicosta minor, (B) Calliacantha natans, (C) C. longicaudata, (D) Cosmoeca ventricosa, (E) Crinolina isefiordensis, (F) Diaphanoeca undulata, $(\mathrm{G})$ D. sphaerica, $(\mathrm{H})$ Pleurasiga minima, $(\mathrm{I})$ $P$. reynoldsii. Scalebar $5 \mu \mathrm{m}$

Figure 2. Light microscopical images of the species from this study. (A-C) Bicosta minor, (D-E) Calliacantha longicaudata, (F) C. natans, (G) Cosmoeca ventriosa, $(\mathrm{H})$ Crinolina isefiordensis, (I-J) Diaphanoeca sphaerica (colony and single specimen), (K) D. undulata, (L) Pleurasiga minima, (M) P. reynoldsii. Scalebar for all images given in $(F)$ with $5 \mu \mathrm{m}$, except for (I) with different scale and scalebar at $5 \mu \mathrm{m}$.

Figure 3. Molecular phylogeny of choanoflagellates based on a concatenated twogene dataset. The tree shown was derived by Maximum likelihood analysis based on a combined SSU and LSU rDNA nucleotide sequence alignment. Branches are drawn proportional to the number of nucleotide substitutions per site as indicated by the scale bar at the lower left. Branches receiving 100\% maximum likelihood bootstrap percentages (mIBP) and 1.00 Bayesian Inference posterior probabilities (biPP) support are denoted by an *. mIBP and biPP values are otherwise given above and below branches respectively, only values above $50 \%$ are shown.

Figure 4. Network diagrams of previously unidentified Tara Oceans V9 OTUs matching a newly sequenced species in this paper. Nodes represent individual barcodes and edges are present between barcodes if there is exactly one DNA sequence difference between them. The barcode within each OTU matching our new sequence is in red, and all other Tara Oceans barcodes are in blue. Node sizes are proportional to barcode global abundance.

Figure 5 A-E. Presence (red) or absence (white) of newly sequenced species that were identified as matching a V9 OTU in the Tara Oceans data set within the 0.8-5 $\mu \mathrm{m}$ or 5-20 $\mu \mathrm{m}$ size fraction, either at the surface or at the deep chlorophyll maximum (DCM) for all Tara sampling stations with available data. A Calliacantha natans; B Crinolina isefiordensis; C Diaphanoeca undulata; D Pleurasiga minima and E 
Pleurasiga reynoldsii. Although loricae for these species may measure larger than 5 or $20 \mu \mathrm{m}$, we display data for the $0.8-5 \mu \mathrm{m}$ and 5-20 $\mu \mathrm{m}$ size fractions, since individual cells are expected to have been pulled out of their loricae during the filtration process that isolated individual size fractions.

Table 1. Relative abundances in percentage for the different sampling sites and species.

Table 2. Nucleotide sequences used to create the multigene phylogeny shown in Fig.

3. Reference Numbers are GenBank Accession.

Table 3. Matches of V9 $18 \mathrm{~S}$ barcode sequences in the Tara Oceans OTU data set. For each newly sequenced species, we searched the V9 portion of the $18 \mathrm{~S}$ locus against the set of Tara Oceans V9 metabarcodes. Tara OTU Match \%: the percent identity of the best match; Tara OTU Abundance Rank: the rank abundance of the matched Tara OTU within all choanoflagellate OTUs sequenced; Tara OTU GenBank Best Match: the best match within described choanoflagellate species in GenBank for the Tara V9 OTU; Tara OTU GenBank Match \%: the percent identity of the match between the Tara OTU and the GenBank sequence. 

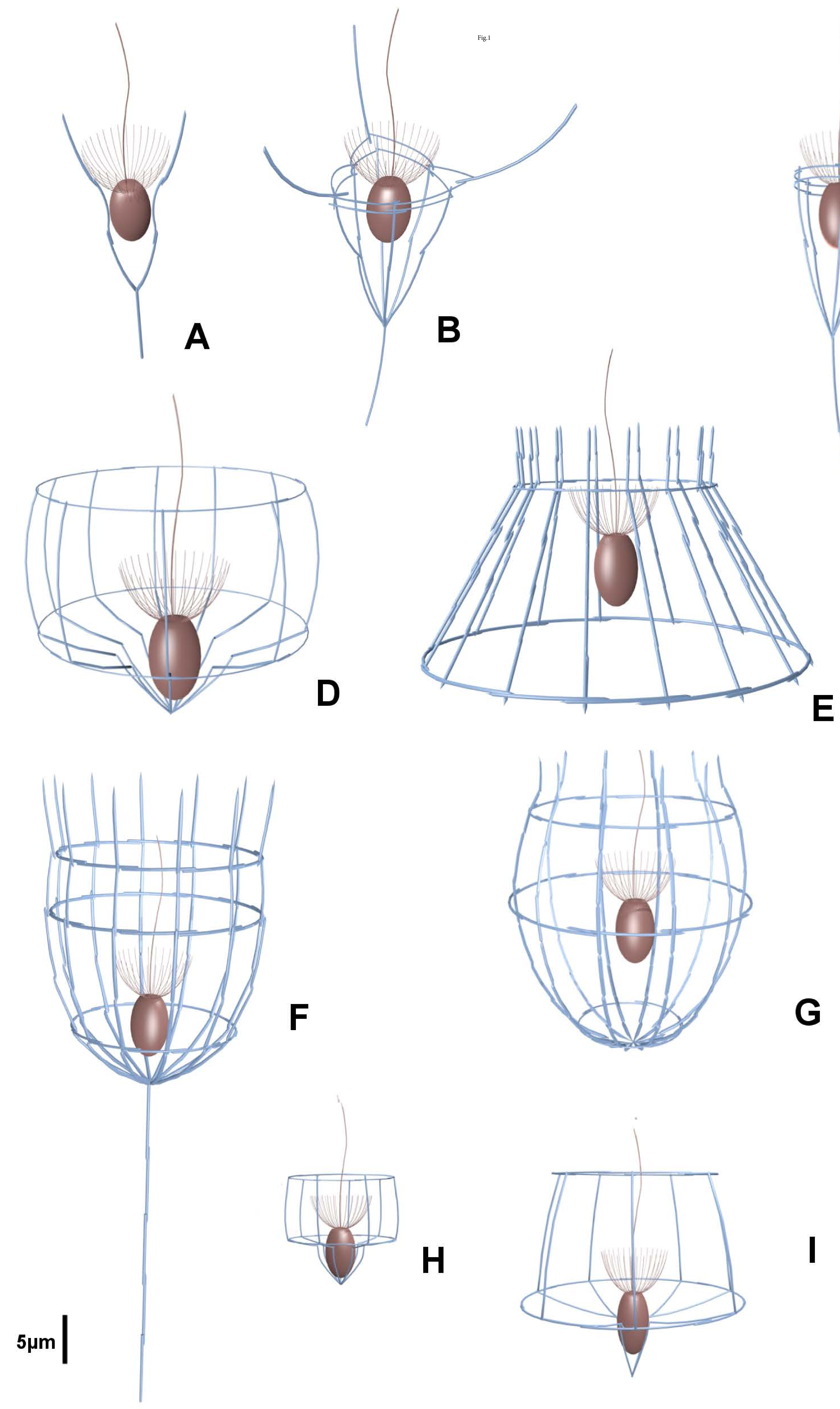

G

C 


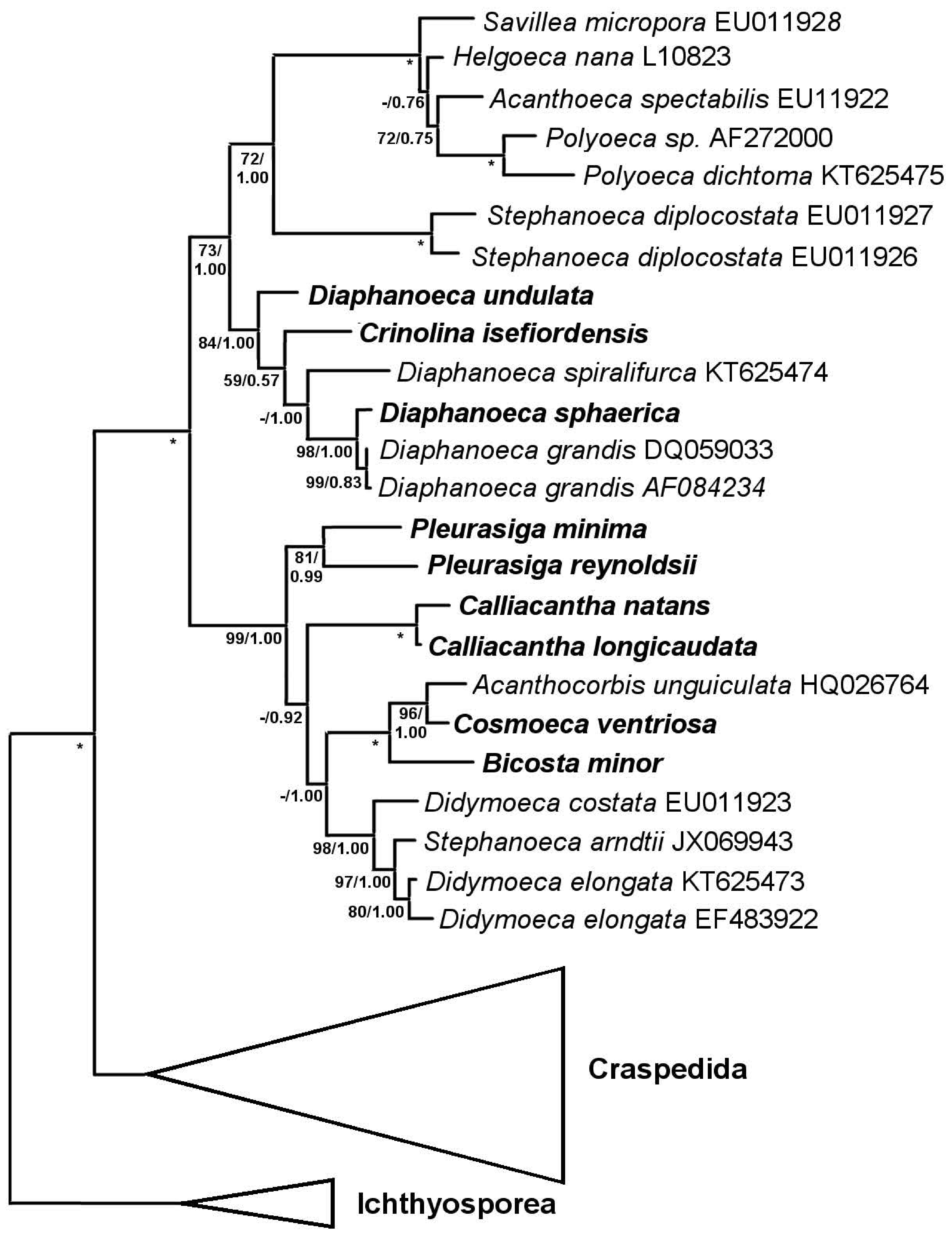




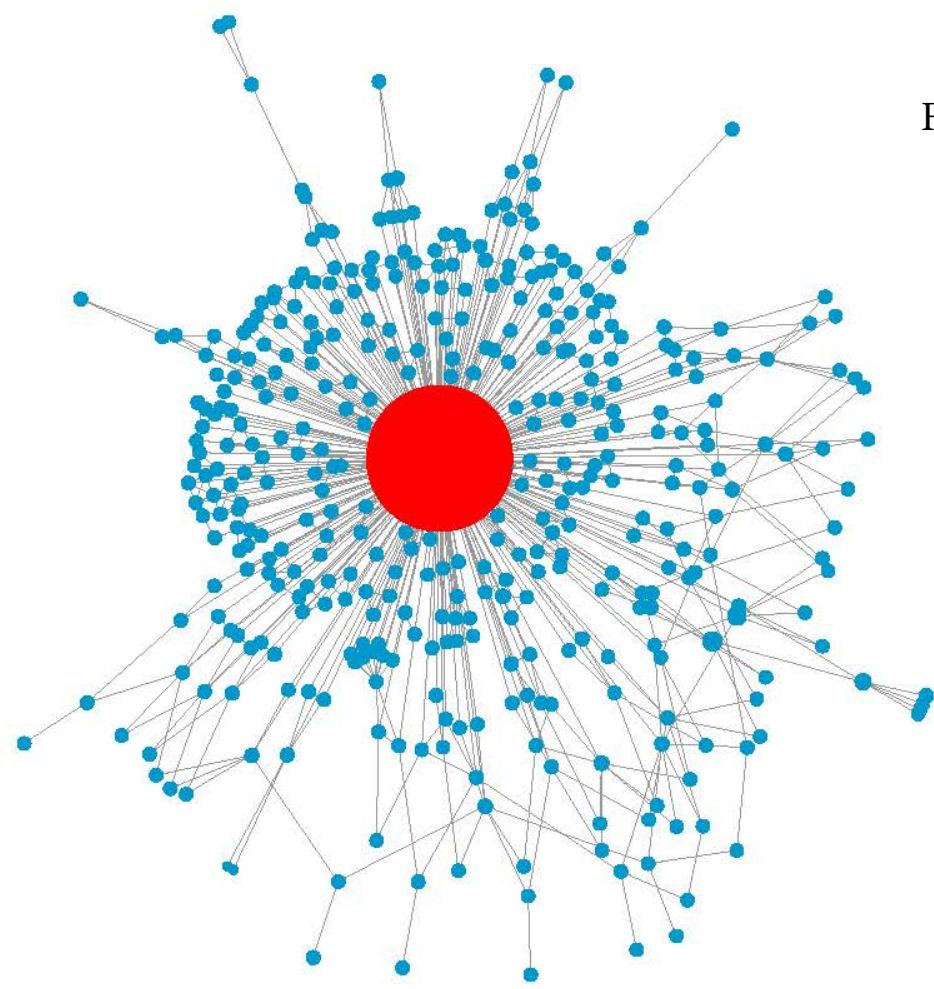

Calliacantha natans

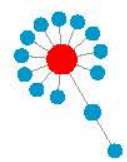

Pleurasiga minima
Fig.4

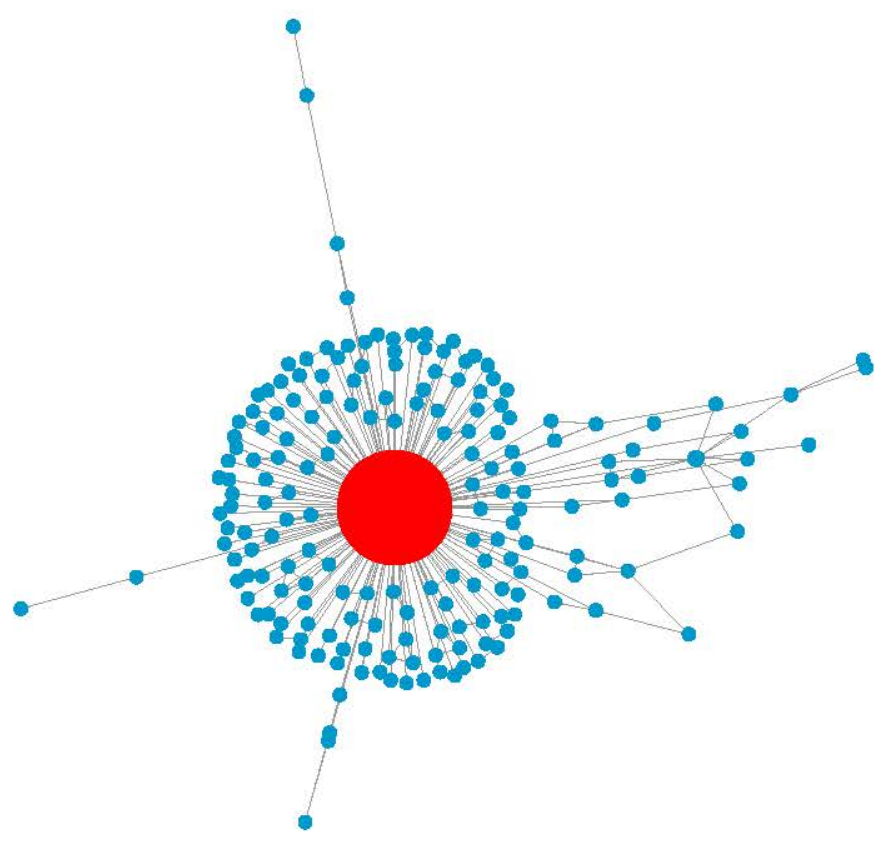

Diaphanoeca undulata

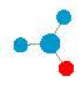

Pleurasiga reynoldsii

Crinolina isefiordensis 
Table 1

\begin{tabular}{|c|c|c|c|}
\hline & 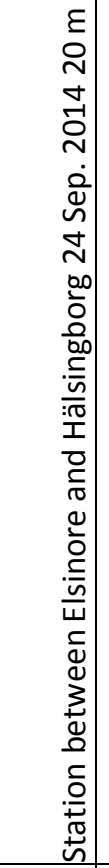 & 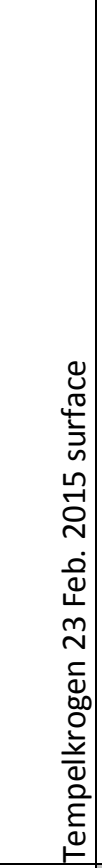 & 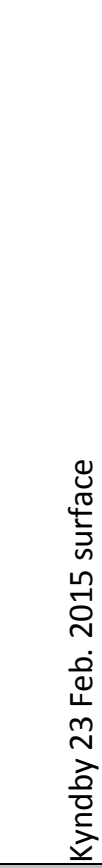 \\
\hline Bicosta minor (Reynolds 1976) Leadbeater 1978 & 2.0 & 14.9 & 16.7 \\
\hline Calliacantha longicaudata (Leadbeater 1975) Leadbeater 1978 & & 13.3 & 14.2 \\
\hline Calliacantha natans (Grøntved 1956) Leadbeater 1978 & & 5.3 & 4.3 \\
\hline Cosmoeca ventricosa Thomsen 1984 & 20.3 & & \\
\hline Crinolina isefiordensis Thomsen 1976 & 3.7 & $\mathbf{x}$ & \\
\hline Diaphanoeca sphaerica Thomsen 1982 & & 3.2 & 4.3 \\
\hline Diaphanoeca undulata Thomsen 1982 & 2.4 & & \\
\hline Pleurasiga minima Throndsen 1970 & 1.2 & 32.4 & 33.3 \\
\hline Pleurasiga reynoldsii Throndsen 1970 & & 12.2 & 6.8 \\
\hline
\end{tabular}


Table 2

\begin{tabular}{|c|c|c|}
\hline Species & SSU & LSU \\
\hline \multicolumn{3}{|l|}{ Acanthoecida } \\
\hline Acanthocorbis unguiculata & HQ026764 & - \\
\hline Acanthoeca spectabilis & AF084233 & EU011933 \\
\hline Bicosta minor & KU587839 & - \\
\hline Calliacantha longicaudata & KU587840 & KU587841 \\
\hline Calliacantha natans & KU587842 & KU587843 \\
\hline Cosmoeca ventricosa & KU587844 & - \\
\hline Crinolina isefiordensis & KU587845 & - \\
\hline Diaphanoeca grandis & DQ059033 & EU011939 \\
\hline Diaphanoeca grandis & AF084234 & - \\
\hline Diaphanoeca spiralifurca & KT625474 & - \\
\hline Diaphanoeca sphaerica & KU587846 & KU587847 \\
\hline Diaphanoeca undulata & KU587848 & - \\
\hline Didymoeca costata & EU011923 & EU011938 \\
\hline Didymoeca elongata & KT625473 & - \\
\hline Helgoeca nana & L10823 & EU011934 \\
\hline Pleurasiga minima & KU587849 & KU587850 \\
\hline Pleurasiga reynoldsii & KU587851 & KU587852 \\
\hline Polyoeca sp. & AF272000 & - \\
\hline Polyoeca dichotoma & KT625475 & - \\
\hline Savillea micropora & EU011928 & EU011944 \\
\hline Stephanoeca arndtii & JX069943 & - \\
\hline Stephanoeca diplocostata (Australia) & EU011926 & EU011947 \\
\hline Stephanoeca diplocostata (France) & EU011927 & EU011943 \\
\hline \multicolumn{3}{|l|}{ Craspedida } \\
\hline Choanoeca perplexa & AF084232 & EU011937 \\
\hline Codosiga gracilis & - & EU011935 \\
\hline Desmarella sp. & AF084231 & - \\
\hline Monosiga brevicollis & AF084618 & AY026374 \\
\hline Monosiga sp.(ATCC 50635) & AF084230 & EU011940 \\
\hline Salpingoeca abyssalis & DQ995808 & - \\
\hline Salpingoeca amphoridium & DQ059032 & EU011942 \\
\hline Salpingoeca infusionum & AF100941 & AY026380 \\
\hline Salpingoeca sp.(ATCC50938) & - & HQ026767 \\
\hline Salpingoeca sp. (ATCC50153) & EU011929 & EU011945 \\
\hline Salpingoeca sp.(ATCC50929) & EU011930 & EU011926 \\
\hline Salpingoeca rosetta (ATCC50818) & EU011924 & EU011941 \\
\hline Salpingoeca sp.(ATCC50931) & HQ026770 & HQ026771 \\
\hline Salpingoeca sp. (Mallorca) & HQ026772 & - \\
\hline Salpingoeca urceolata & EU011931 & EU011948 \\
\hline \multicolumn{3}{|l|}{ Ichthyosporea } \\
\hline Amoebidium parasiticum & Y19155 & EU011932 \\
\hline Ichthyophonus hoferi & U25637 & AY026370 \\
\hline
\end{tabular}


Table 3

\begin{tabular}{|c|c|c|c|c|}
\hline Species & $\begin{array}{l}\text { Tara OTU } \\
\text { Match \% }\end{array}$ & $\begin{array}{c}\text { Tara OTU } \\
\text { Abundance Rank }\end{array}$ & $\begin{array}{c}\text { Tara OTU GenBank } \\
\text { Best Match }\end{array}$ & $\begin{array}{c}\text { Tara OTU GenBank } \\
\text { Match \% }\end{array}$ \\
\hline Bicosta minor & 97 & 23 & Didymoeca costata & 83 \\
\hline Calliacantha longicaudata & 96 & 7 & Didymoeca costata & 87 \\
\hline Calliacantha natans & 100 & 2 & Didymoeca costata & 88 \\
\hline Cosmoeca ventricosa & 99 & 15 & Didymoeca costata & 89 \\
\hline Crinolina isefiordensis & 100 & 101 & Diaphanoeca grandis & 90 \\
\hline Diaphanoeca sphaerica & 94 & 11 & Diaphanoeca grandis & 94 \\
\hline Diaphanoeca undulata & 100 & 16 & Savillea micropora & 91 \\
\hline Pleurasiga minima & 100 & 27 & Didymoeca costata & 92 \\
\hline Pleurasiga reynoldsii & 100 & 39 & Didymoeca costata & 89 \\
\hline
\end{tabular}

